\title{
Rapid assessment checklist for green roof ecosystem services in Bangkok, Thailand
}

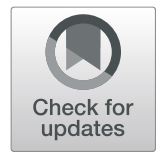

\author{
Rattanapan Phoomirat ${ }^{1,2}$, Nipada Ruankaew Disyatat ${ }^{2}$, Tae Yoon Park ${ }^{3}$, Dong Kun Lee ${ }^{4}$ and \\ Pongchai Dumrongrojwatthana ${ }^{2^{*}}$
}

\begin{abstract}
Background: A green roof is a man-made ecosystem created when a rooftop is covered with substrate and vegetation. Although green roof ecosystems (GREs) are able to provide ecosystem services, there is currently no assessment tool available to specifically evaluate this. Therefore, the aim of this study was to develop a rapid assessment checklist (RAC) to assess GRE services (GRES), which was developed and tested on 10 green roofs in Bangkok, Thailand.

Results: The RAC consisted of 46 proxy indicators (33 qualitative and 13 quantitative indicators) encompassing various aspects of GRESs. The GRES values or scores varied according to structural differences in the green roofs. The average score (from a maximum of 100) of total ecosystem services was $61 \pm 7$, which could be inferred as a good performance in ecosystem service provision. The highest scores were obtained from the regulating services at $68 \pm 7$. The lowest average score was $53 \pm 11$ from the provisioning services.

Conclusions: The RAC was able to evaluate the levels of GRES provided by the selected green roofs, enabling the meaningful comparison of their potential capability to provide GRES. Therefore, this RAC could be an innovative tool for evaluation of four categories of GRES.
\end{abstract}

Keywords: Vegetated roof, Evaluation, Composite indicator, Urban ecosystem, Ecosystem management

\section{Background}

Green roofs are installations of growing media and plants on the roof of buildings (Oberndorfer et al. 2007). They are usually designed and constructed for specific architectural and urban planning purposes, and so current green roofs are diverse, depending on the variation in the amount and structure of the used soil, and the variety and relative proportions of plant species of varying forms. In a sense, green roofs are man-made ecosystems embedded in an urban landscape and are found in cities worldwide. Green roofs can provide various ecological and environmental benefits (Berardi et al. 2014). For example, green roofs usually reduce the building temperature and surface heat (Stone et al. 2012),

\footnotetext{
* Correspondence: dpongchai@hotmail.com

${ }^{2}$ Department of Biology, Faculty of Science, Chulalongkorn University, Bangkok 10330, Thailand

Full list of author information is available at the end of the article
}

decrease the energy consumption in the building (Sfakianaki et al. 2009), absorb atmospheric carbon dioxide (Getter et al. 2009), preserve the diversity of plants (Cook-Patton and Bauerle 2012), and function as habitats for birds and other animals (Fernandez and Gonzalez-R 2010). In addition, green roofs can increase urban gardening (Whittinghill et al. 2013).

Ecosystem services are the benefits humans obtain from ecosystems and can be classified into the four service categories of (i) regulating services: the benefits obtained from regulation of essential ecological process, (ii) provisioning services: the products or natural resources, (iii) cultural services: the non-material benefits, and (iv) supporting services: habitat provision and the services that are the basis of other ecosystem services (Millennium Ecosystem Assessment 2005). As green roofs can provide many environmental benefits to humans, they can play a role as ecosystem service providers. A review

\section{Springer Open}

(c) The Author(s). 2020 Open Access This article is licensed under a Creative Commons Attribution 4.0 International License, which permits use, sharing, adaptation, distribution and reproduction in any medium or format, as long as you give appropriate credit to the original author(s) and the source, provide a link to the Creative Commons licence, and indicate if changes were made. The images or other third party material in this article are included in the article's Creative Commons licence, unless indicated otherwise in a credit line to the material. If material is not included in the article's Creative Commons licence and your intended use is not permitted by statutory regulation or exceeds the permitted use, you will need to obtain permission directly from the copyright holder. To view a copy of this licence, visit http://creativecommons.org/licenses/by/4.0/. 
of the existing literature by Francis and Jensen (2017) showed that most studies on green roofs have focused on the regulating aspect of ecosystem services, such as mitigation of the urban heat island, reduction of air pollution, and the reduction of energy consumption of buildings, and pointed out that in these studies usually only one type of ecosystem service was individually investigated. There is also little research on green roofs ecosystem services (GRES) in Thailand. Until now, only one study has been reported on this and it was focused only on the energy saving potential of green roofs in Thailand (Permpituck and Namprakai 2012). Furthermore, interactions and tradeoffs among ecosystem services in general can occur (Rodríguez et al. 2006). Therefore, to understand the potential of green roofs as an ecosystem service provider, it is necessary to include as many ecosystem services as possible in the investigation.

Knowledge of ecosystem services would give relevant stakeholders greater recognition and consideration during planning and management of green roofs and their surrounding urban landscape. In order to provide the necessary knowledge, an assessment tool is needed to identify and quantify various types of ecosystem services. A meaningful result from the assessment of GRES would allow stakeholders to identify the weak and strong points of existing green roofs and could then be used to design green roofs that have a greater potential to provide ecosystem services to the urban populations.

Urban ecosystems can provide high values of ecosystem services that are in demand for enhancing human well-being (Grunewald and Bastian 2017). However, the implementation of urban green spaces with multiple ecosystem services is hindered by the lack of assessment tools that provide an integrated analysis of ecosystem services. Evaluation of individual urban ecosystem services and understanding the tradeoffs and synergies among services at the citywide scale have emerged as the major challenges (Haase et al. 2014).

Several assessment tools have been developed for the evaluation of ecosystem services of natural ecosystems, such as the (i) Ecosystem Services Review (ESR), which is a qualitative tool used for identifying, prioritizing, and assessing the impacts of ecosystem services (Hanson et al. 2012), (ii) Integrated Valuation of Ecosystem Services and Tradeoffs (InVEST), which assesses the ecological production and subsequent economic valuation (Sharp et al. 2016), and (iii) Toolkit for Ecosystem Service Site-based Assessment (TESSA), which is a suite of tools that is used for evaluating and monitoring ecosystem services at a site scale (Peh et al. 2013). However, the concepts, methods, and ability to assess ecosystem services with these tools vary greatly, and so the selection of suitable ecosystem service assessment tools is required. Because there is no specific tool for urban ecosystems, some assessments have been conducted using a combination of existing tools. For example, Sieber (2015) used a combination of Urban-ESR (an adaptation of corporate ESR) and InVEST tools to assess urban ecosystem services in Singapore. The use of both tools reflected the conditions at the individual study sites better than using either assessment tool alone.

However, general ecosystem service assessment tools have limitations in the aggregation of ecosystem services. Specifically, some services, usually cultural services, have no market value (Daniel et al. 2012), and cannot be combined with values from other material services that always have a market value. Therefore, Alam et al. (2016) proposed the Ecosystem Services Composite (ESC), a framework of a composite indicator for urban ecosystem services, within which different variables would be transformed into common units before the final aggregation into a single value that could be easily communicated with the relevant stakeholders. The ESC approach was criticized for poorly representing the relationship between ecosystem components, processes, and services, and likely resulting in an oversimplification of a complex ecosystem. However, it can facilitate communication between science and policy owing to the provision of a single value result and the use of simple familiar indicators.

Currently, there is no specific ecosystem service assessment tool for green roofs, yet quantification of their benefits should be encouraged. So, to evaluate and analyze the effectiveness of green roof performances, in this study, a composite indicator was used to develop a Rapid Assessment Checklist (RAC) for GRES. A short time requirement for conducting the assessment is preferable, since green roofs are public spaces and some conventional assessments can disturb the user. Furthermore, to encourage the public to become aware of the importance of green roofs, stakeholders, such as building owners, officers, or gardeners, should be encouraged to participate in the assessment process. Therefore, the development of a rapid, user-friendly assessment tool that requires a small amount of time for conducting was focused upon in this study. The developed RAC for assessment of GRES was then tested on ten green roofs in Bangkok, Thailand. This study, therefore, contributes to the growing knowledge on the GRES offered in a tropical region.

\section{Methods}

\section{Study sites and data collection}

Green roofs in the Bangkok metropolitan area were first identified using the information from the Division of Public Health and Environmental Strategy of the Bangkok Metropolitan Administration. The green roofs were on residential (condominiums) and business (hotels, hospitals, universities, or department store) buildings. Requests 
for permission to conduct research were sent to 41 buildings with green roofs. However, only 10 buildings granted access for the research: Aor Por Ror Building (APR), Anantara Siam Bangkok Hotel (ASH), Crowne Plaza Bangkok Lumpini Park Hotel (CPB), Mahitaladhibesra Building (MHT), Mitkorn Mansion (MTK), Noble House Phayathai (NHP), Park Venture Ecoplex (PVE), Siam Green Sky (SGK), SG Tower Building (SGT), and the 60th Anniversary Building (SXV). The main reason for a low permission response $(24.4 \%)$ was that the owners were concerned that the data collection might bother their customers or intrude on the privacy of the residents. A map showing the green roof locations is presented in Fig. 1, and their general characteristics are described in Table 1, respectively.

The vegetation types on each green roof were observed and classified into four types based on their growth forms (trees, shrubs, herbs, and grasses). The floor area, green roof area, green area, and plant cover, in terms of trees, shrubs, herbs, and grasses, were measured for calculating the percentage of green roof area, green area, and plant cover. Design types (i.e., garden bed and flowerpot green roof) were identified for each green roof. Although the actual functions of some green roofs were not clearly indicated by the building owners, the intended functions could be determined by observing the utilization of each green roof, as shown in Table 1.

\section{Construction of the RAC for the assessment of GRES}

The RAC tool for the assessment of GRES was constructed based on the methods outlined in the ESC
(Alam et al. 2016). Five procedures were included in the checklist construction: (i) defining the scope of the study, (ii) selecting the indicators, (iii) normalizing the variables, (iv) weighting the variables, and (v) aggregating the normalized and weighted variables. These steps are described in detail as follows.

\section{Defining the scope of the study}

This RAC tool was designed to evaluate green roofs as potential providers of ecosystem services, and so the indicators selected for the checklist included all four ecosystem service categories, namely regulation services (i.e., gas regulation, climate regulation, storm water regulation, waste treatment, and pollination), provisioning services (i.e., food provision), cultural services (i.e., aesthetic information, recreation, and education), and supporting services (i.e., habitat function).

According to the scope of this study, the review of ecosystem services provided by green roofs was conducted. Based on each ecosystem service definition, the environmental benefits of green roofs could be classified into regulating, provisioning, cultural, or supporting ecosystem services. For example, the ability of green roofs to mitigate the urban heat island is considered as one aspect of the regulating services because it corresponds to one of the environmental functions to regulate and maintain favorable conditions for human livelihood (Millennium Ecosystem Assessment 2005; Stone et al. 2012). Provisioning services on green roofs were mostly found as rooftop agriculture, which could provide food

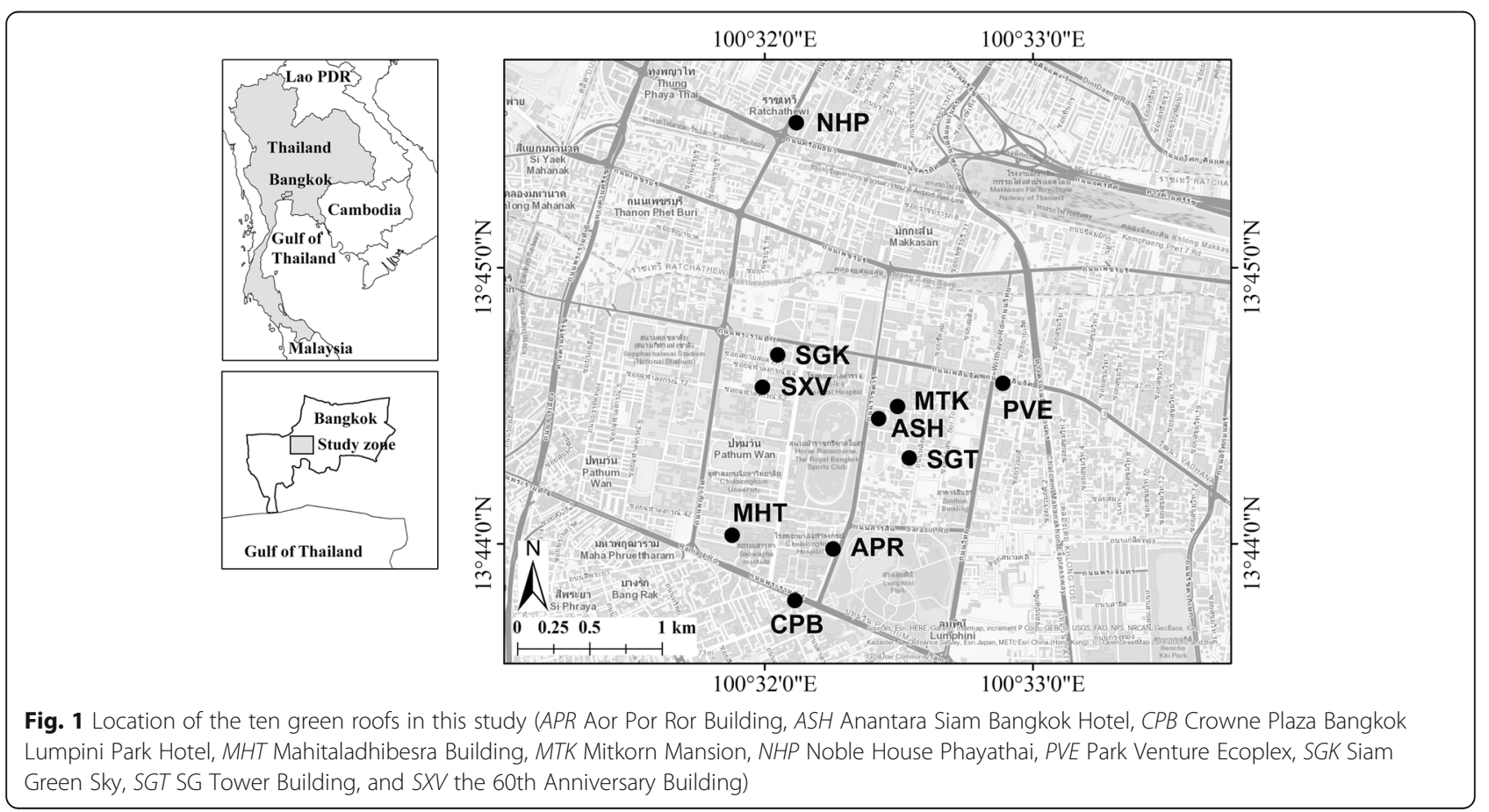


Table 1 General characteristics of the ten green roofs used in this study

\begin{tabular}{|c|c|c|c|c|c|c|}
\hline $\begin{array}{l}\text { Green roof study } \\
\text { site }\end{array}$ & Building type & $\begin{array}{l}\text { Height } \\
(\mathrm{m})\end{array}$ & $\begin{array}{l}\text { Total green roof area } \\
\left(\mathrm{m}^{2}\right)\end{array}$ & $\begin{array}{l}\text { Plant forms }(T / S / H / \\
G)^{*}\end{array}$ & $\begin{array}{l}\text { Design } \\
\text { type }\end{array}$ & Intended function \\
\hline$\overline{\mathrm{APR}}$ & Hospital & 19.8 & 891 & $\mathrm{~T} / \mathrm{S} / \mathrm{H} / \mathrm{G}$ & $\begin{array}{l}\text { Garden } \\
\text { bed }\end{array}$ & Recreation \\
\hline $\mathrm{ASH}$ & Hotel & 6.6 & 2872 & $\mathrm{~T} / \mathrm{S} / \mathrm{H} / \mathrm{G}$ & $\begin{array}{l}\text { Garden } \\
\text { bed }\end{array}$ & Recreation \\
\hline CPB & Hotel & 16.5 & 264 & $\mathrm{~T} / \mathrm{S}$ & Flowerpot & $\begin{array}{l}\text { Space for vegetation } \\
\text { maintenance }\end{array}$ \\
\hline MHT & University & 16.5 & 287 & $\mathrm{~T} / \mathrm{S} / \mathrm{H}$ & $\begin{array}{l}\text { Garden } \\
\text { bed }\end{array}$ & Recreation \\
\hline MTK & Condominium & 6.6 & 942 & $\mathrm{~T} / \mathrm{S} / \mathrm{H}$ & $\begin{array}{l}\text { Garden } \\
\text { bed }\end{array}$ & Recreation \\
\hline $\mathrm{NHP}$ & Condominium & 26.4 & 656 & $\mathrm{~T} / \mathrm{S} / \mathrm{H}$ & $\begin{array}{l}\text { Garden } \\
\text { bed }\end{array}$ & Recreation \\
\hline PVE & Office & 26.4 & 526 & $\mathrm{~T} / \mathrm{S} / \mathrm{G}$ & $\begin{array}{l}\text { Garden } \\
\text { bed }\end{array}$ & Recreation \\
\hline SGK & $\begin{array}{l}\text { Department } \\
\text { store }\end{array}$ & 23.1 & 1098 & $H / G$ & $\begin{array}{l}\text { Garden } \\
\text { bed }\end{array}$ & Education \\
\hline SGT & Office & 36.3 & 238 & $\mathrm{~T} / \mathrm{S} / \mathrm{H}$ & Flowerpot & Electrical equipment installation \\
\hline SXV & University & 29.7 & 1159 & $\mathrm{~T} / \mathrm{S}$ & Flowerpot & Recreation \\
\hline
\end{tabular}

Notes: ${ }^{*} \mathrm{~T}, \mathrm{~S}, \mathrm{H}$, and $\mathrm{G}$ refer to trees, shrubs, herbs, and grasses, respectively

production (Kim et al. 2018). In addition, the role of green roofs as educational area for scientific research was observed and so this aspect was then included in the cultural services (Carter and Fowler 2008; Mocior and Kruse 2016). Lastly, green roofs could serve as habitats for birds and other animals, and this ability to maintain a diversity of animals is considered as one of the supporting services (Fernandez and Gonzalez-Redondo 2010; Millennium Ecosystem Assessment 2005). Finally, 10 green roof ecosystem services were selected for investigation in this study (Additional file 1: Table S1). Selection of indicators corresponding to the chosen ecosystem services is described in detail in the next step.

\section{Selecting the indicators}

The ESC proposed two types of indicators, namely direct and proxy indicators. Direct indicators are the indicators that are directly relevant to ecosystem services and some of them might require complex methods for measurement. In contrast, proxy indicators are surrogate indicators of each ecosystem service, where their value can indirectly indicate levels of ecosystem services. For example, carbon sequestration and carbon storage are direct indicators for assessing performance for gas regulation in regulating services, whereas the green ratio and the appearance of woody plants are the proxy indicators that can also affect the potential gas regulation (Pollution Control Department 2013; Whittinghill et al. 2014). The RAC developed in this study focused on the proxy indicators for GRES.
The proxy indicators used in the RAC were selected depending on the following criteria: relevance to green roofs, quantifiability, availability, and information transferability (Alam et al. 2016). Moreover, the indicators were also considered based on the literature and the existing assessment and guidelines for various types of green areas. Therefore, 46 indicators were chosen in this checklist, as presented in Additional file 1: Table S1. The reference values for each indicator were compiled from the suggestions, assumptions, and expectations from various studies and guidelines.

The indicators were selected to represent the ecosystem services provided by green roofs. Several ecosystem services were included in the regulating services, such as gas regulation, climate regulation, and pollination. Therefore, indicators had to be selected from various references, such as study recommendations and the guidelines for green buildings in Bangkok. The factors that affected the regulating services, particularly on green roofs, were chosen first as the indicators (Mentens et al. 2006; Rowe et al. 2006; Currie \& Bass 2008; FLL 2008; Yang et al. 2008; Rowe 2011; Vijayaraghavan and Joshi 2014; MacIvor 2016; Pianella et al. 2017). However, some indicators for regulating services (e.g., the existence of flowering plants, plants with seasonal variety, nesting opportunities, and undisturbed soil) have not been identified or measured on green roofs, and, in these cases, the studies of general gardens were used instead as the references for those regulating service indicators (Home Garden Seed Association [HGSA] 2015; U.S. Fish and Wildlife 2014). To evaluate provisioning services, in 
terms of food provision, the indicators were carefully considered because several conditions of green roofs differ from agricultural areas at the ground level, which could affect the provision of food products. Therefore, the potential of green roofs to provide food in this study was determined by the indicators that were listed in the rooftop agriculture guide (Germain et al. 2008; Egoh et al. 2012; FoodShare 2015; Hurley and Emery 2018). In addition, some indicators were adopted from the study of rooftop farming (Fernandez and Gonzalez-Redondo 2010).

The indicators for assessing cultural services were selected based on the standard criteria for recreational green areas in Bangkok (Office of Natural Resources and Environmental Policy and Planning 2014). Accessibility, number of plants, and facilities for recreation and education were included for evaluating the performances of the recreation area in both the social and environmental aspects (Getter and Rowe 2006; Bieling and Plieninger 2013; Jungels et al. 2013; Ghermandi and Fichtman 2015). Habitat conservation was the major supporting service. Therefore, the important factors for designing biodiverse green roofs were selected for the measurement of supporting services (Banting et al. 2005; Hui and Chan 2011; Torrance et al. 2013; Williams et al. 2014; Wang et al. 2017).

Finally, the indicators were compiled into a RAC for assessing the GRES (Table 2). The checklist was composed of yes/no questions, multiple-choice questions, and open questions for recording information. For ease of use, the indicators in the checklist were grouped into the four categories of specific green roof structures or characteristics, physical factors, biological factors, and maintenance and management.

\section{Normalizing the variables}

Normalization of the variables was performed by transforming the different indicators to the same standard or dimensionless values (Nardo et al. 2005). Categorical scales and min-max were used for data normalization. The collected variables were given a score of $0,0.25,0.5$, or 1 , depending on how much the variables were worth relative to the reference values. For example, if a green roof had trees that could provide shade for the buildings and there were more than one tree per four meters of each building side, then the green roof would receive one point (Office of Natural Resources and Environmental Policy and Planning 2014). If there were woody plants on a green roof, then this green roof would receive one point, otherwise, the green roof would get 0.5 point if there were only herbs or grass (Whittinghill et al. 2014).

4. Weighting the variables
As the aim of this study was to document and evaluate all aspects of ecosystem services potentially provided by green roofs, the RAC assumed that the importance of each ecosystem service was equal and so the indicators were assigned equal weighting. The practice of equal weighting has previously been widely used in several types of environmental assessments, such as environmental impact and footprint and environmental performance index (Hsu and Zomer 2014; Huppes and van Oers 2011; Sala et al. 2018). Moreover, Sharpe and Andrews (2012) analyzed the weighting methods used in the Index of Economic Well-Being, a composite indicator that includes an equal, expert, and user weighting, and found that equal weighting could reduce the disagreement between stakeholders and provide simpler comparisons when compared to other weighting methods.

Thus, all the variables in each ecosystem service were weighted equally. The weight of variables $\left(w_{i}\right)$ was calculated using Eq. (1);

$$
w_{i}=\frac{1}{I D}
$$

where $w_{i}$ is the weight of variables, $\sum_{i=1}^{n} w_{i}=1$ and $0 \leq$ $w_{i} \leq 1$, and $I D$ is the number of indicators in each service.

\section{Aggregating the normalized and weighted variables}

Lastly, the score was aggregated using an arithmetic mean (Talukder et al. 2017). The ESC method developed by Alam et al. (2016) was used in this study and is shown in Eq. (2);

$$
E S C=\frac{\sum_{i=n}^{n} X_{i} w_{i}}{N}
$$

where $X_{i}$ is the normalized variable, $w_{i}$ is the weight of $X_{i}$, and $N$ is the number of ecosystem services.

\section{Evaluation of GRES using the RAC}

After the RAC was constructed, it was used to assess GRES on ten selected green roofs. The checklist items in the green roof structure, physical factors, and biological factors parts were completed by observations and direct measurements, while the data in the maintenance and management parts were collected by observations and interviews with the green roof owner or manager. The assessment was conducted by two users (RP and a research assistant) and each green roof required a half-day for the on-site checklist completion and an additional half-day for data processing and analysis. 
Table 2 The RAC for assessing GRES

\begin{tabular}{|c|c|}
\hline Indicator & Data \\
\hline \multicolumn{2}{|l|}{ Green roof structure } \\
\hline Green roof types & $\square$ Intensive $\square$ Extensive \\
\hline $\begin{array}{l}\text { Green roof area } \\
\text { Percentage of green roof area in total floor area }\end{array}$ & $\begin{array}{l}\% \\
\text { *Green roof area: } \mathrm{m}^{2} \\
\text { Floor area } \quad \mathrm{m}^{2}\end{array}$ \\
\hline Green area of green roof & $m^{2}$ \\
\hline $\begin{array}{l}\text { Green roof height } \\
\text { Floor that the green roof is located on }\end{array}$ & level(s) \\
\hline $\begin{array}{l}\text { Substrate depth } \\
\text { Garden bed: depth of growing media layer } \\
\text { Flowerpot: average of soil depth in flowerpots }\end{array}$ & $\mathrm{cm}$. \\
\hline $\begin{array}{l}\text { Continuous coverage of substrate } \\
\text { Percentage of area covered by substrate in green roof }\end{array}$ & $\begin{array}{l}\% \\
{ }^{*} \text { Green roof area } \quad \mathrm{m}^{2} \\
\text { Substrate covered area } \quad \mathrm{m}^{2}\end{array}$ \\
\hline Drainage & 口 Yes No \\
\hline $\begin{array}{l}\text { Area exposed to sunlight } \\
\text { Percentage of sunlight-exposed concrete area in total hardscape area }\end{array}$ & $\begin{array}{l}\% \\
\text { *Total hardscape area } \mathrm{m}^{2} \\
\text { Concrete area that exposed to sunlight }\end{array}$ \\
\hline $\begin{array}{l}\text { Permeable surface area } \\
\text { Percentage of permeable surface area in a green roof }\end{array}$ & $\begin{array}{l}\% \\
{ }^{*} \text { Green roof area } \quad \mathrm{m}^{2} \\
\text { Permeable surface area } \quad \mathrm{m}^{2}\end{array}$ \\
\hline $\begin{array}{l}\text { Storage reservoirs } \\
\text { Existence of any water containers, e.g., bird baths and barrels, and ponds }\end{array}$ & aYes DNo \\
\hline $\begin{array}{l}\text { Water sources } \\
\text { E.g., ponds, swimming pools, basins, and water tap }\end{array}$ & $\square$ Yes $\square$ No \\
\hline Connectivity to natural habitat & $\square$ Yes $\square$ No \\
\hline
\end{tabular}

The near green area at ground level within a 200-m radius from the green roof

\section{Physical factors}

Light soil

口 Yes $\square$ No

$(\mathrm{pH})$

Soil pH

Undisturbed soil

Opened area that is not disturbed by vegetation or any constructions

Topographic variation

Provision of topographic variety

E.g., sloped surfaces, different heights of garden beds, flowerpots, and edging

Nesting opportunities

Provision of elements for nesting of birds and insects

E.g., bare area, birdhouses, bee houses, tall shrubs, and branches

Perching habitat

Provision of elements for attraction insects and birds to perch, e.g., branches, logs, and rocks

Sunlight hours on green roof

\section{Biological factors}

Major vegetation cover

Majority of vegetation types that have the most percentage of plant cover in total green roof area

Woody plants

E.g., trees and shrubs

Vegetation species

Majority of plant species that mostly found on the green roof

Planting systems

Phytoremediation potential of plant

$\square$ Yes $\square$ No

$\square$ Yes $\square$ No

a Yes $\square$ No

$\square$ Yes $\square$ No

Hours/day

Tree cover:

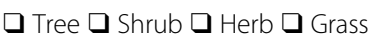

Shrub cover:

Herb cover:

Grass cover:

$\%$

$\%$

$\%$

$\%$

a Yes No

$\square$ Evergreen species $\square$ Deciduous species

$\square$ Monoculture $\square$ Polyculture

$\square$ Yes $\mathrm{No}$ 
Table 2 The RAC for assessing GRES (Continued)

\begin{tabular}{|c|c|}
\hline Indicator & Data \\
\hline Flowering plants & $\square$ Yes $\square$ No \\
\hline Plants with seasonal variety & $\square$ Yes $\square$ No \\
\hline Plant species selection & $\square$ Exotic species $\square$ Native species $\square$ Both \\
\hline Number of trees & tree(s) \\
\hline Number of plants that provide shade for the building in each building side & $\begin{array}{l}\text { Length in each building side: } \mathrm{m} \text {. } \\
\text { Number of plants in each building side } \\
\text { tree(s) }\end{array}$ \\
\hline $\begin{array}{l}\text { Vertical structure of plants } \\
\text { Percentage of tree covered area in total plant cover area }\end{array}$ & $\%$ \\
\hline Edible plants & $\square$ Yes $\square$ No \\
\hline Available crop yields & $\square$ Yes $\square$ No \\
\hline Crop damage by animals & $\square$ Yes $\square$ No \\
\hline Plant with long blooming season & $\square$ Yes $\square$ No \\
\hline \multicolumn{2}{|l|}{ Maintenance and management } \\
\hline Fertilizer application & $\square$ Yes $\square$ No \\
\hline Pesticide used & $\square$ Yes $\square$ No \\
\hline $\begin{array}{l}\text { Water access } \\
\text { E.g., water tap }\end{array}$ & $\square$ Yes \\
\hline Drip irrigation system & $\square$ Yes $\square$ No \\
\hline $\begin{array}{l}\text { Sun protection } \\
\text { E.g., sunblock garden netting mesh }\end{array}$ & $\square$ Yes $\square$ No \\
\hline $\begin{array}{l}\text { A wind breaker } \\
\text { E.g., windbreak mesh }\end{array}$ & $\square$ Yes $\square$ No \\
\hline $\begin{array}{l}\text { Messy appearance } \\
\text { E.g., dirty, untidy, and abandoned area }\end{array}$ & $\square$ Yes $\square$ No \\
\hline $\begin{array}{l}\text { Accessibility } \\
\text { Permission to use green roof }\end{array}$ & 口 Yes $\square$ No \\
\hline Number of building visitors/customers & person(s)/day \\
\hline $\begin{array}{l}\text { Facility for recreation } \\
\text { E.g., chairs, tables, sunshades, footpath, lights, a swimming pool, and playground }\end{array}$ & 口 Yes $\square$ No \\
\hline $\begin{array}{l}\text { Facility for education } \\
\text { E.g., plant species labels }\end{array}$ & 口 Yes $\square$ No \\
\hline $\begin{array}{l}\text { Education activities } \\
\text { E.g., green roof tour or ecotourism }\end{array}$ & 口 Y Y No \\
\hline
\end{tabular}

The results from the assessment were demonstrated in scores of each ecosystem service and total amount of ecosystem service. Radar charts were constructed with four spokes, each representing one of the four ecosystem service categories. The performance GRES could be interpreted from the ecosystem service scores, and the levels of performance were assigned using interval width and a four-point Likert scale interpretation (Brown

Table 3 Assignment of performance levels of ecosystem service values

\begin{tabular}{ll}
\hline Performance level & Definition \\
\hline Poor & - Providing low ecosystem services \\
(Score: 0-39) & - The indicators achieved less than $40 \%$ of the reference values, then the green roof lacks several desirable characteristics \\
Intermediate & - Providing moderate ecosystem services \\
(Score: $40-59)$ & - The indicators achieved $40-59 \%$ of the reference values, then some of desirable characteristics are found \\
Good & - Providing generally high ecosystem services \\
(Score: $60-79)$ & - The indicators achieved $60-79 \%$ of the reference values, then most of desirable characteristics are found \\
Excellent & - Providing high ecosystem services \\
(Score: $80-100)$ & - The indicators achieved more than $80 \%$ of the reference values, then most or all of desirable characteristics are found \\
\hline
\end{tabular}


2010) as: poor (0-39), intermediate (40-59), good (60$79)$, and excellent (80-100) performances for providing ecosystem services. The definitions of performance levels are shown in Table 3. Cluster analysis was used to classify the green roofs into groups based on the ecosystem service scores. Pearson analysis was used to investigate the relationship between the different ecosystem service scores. All analyses were performed using the SPSS version 22.0 software.

\section{Results}

\section{Characteristics of the green roofs}

All green roofs were of the intensive green roof type. They were located on the buildings in the inner-city area of Bangkok, the capital city of Thailand. Seven of these green roofs were constructed for recreation purposes (Table 1). Of the other three, CPB was used as a space for maintenance of ornamental plants, especially young plants, SGK was used for urban agricultural education, and SGT was used for installation of electrical equipment, including antennas and air conditioner units. Five green roofs, APR, ASH, CPB, MTK, and SGT, were located within $0.06,0.12,0.19,0.22$, and $0.40 \mathrm{~km}$, respectively, of large ground-level green areas (parks and golf courses). The APR, ASH, MHT, MTK, NHP, PVE, and SXV were open rooftop areas on residential buildings (condominiums) and business buildings (hotel, office, hospital, and universities), where building visitors and staffs could use the green roofs during the office hours. However, SGK was on a department store and people could visit the green roof occasionally when workshops or agricultural activities were conducted, while $\mathrm{CPB}$ and SGT were green roofs with restricted access, meaning people were not allowed to use the green roof.

Most of the green roofs were used as a recreation and exercise area, with APR, ASH MTK, and NHP containing
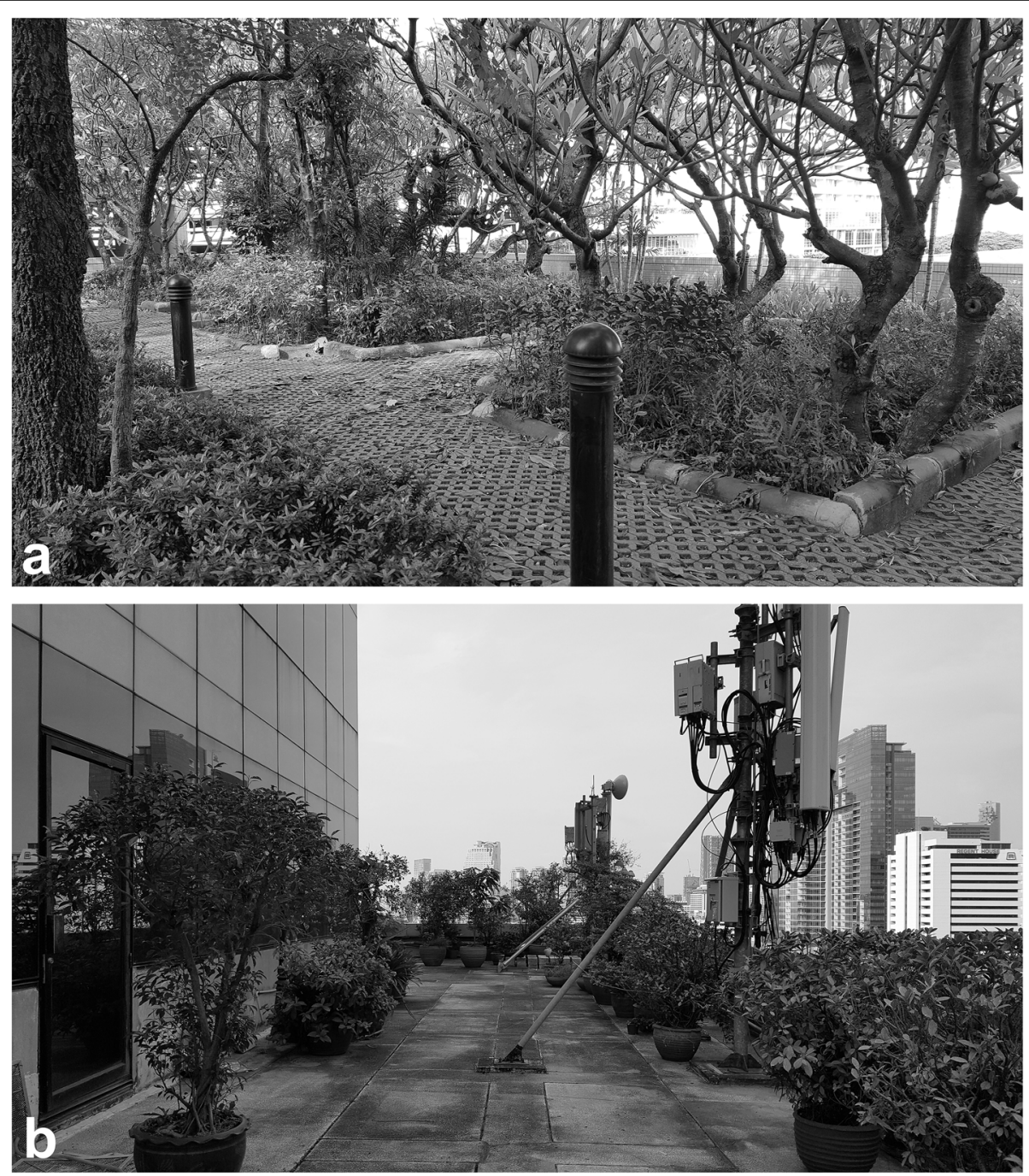

Fig. 2 Examples of the green roofs in this study: a MHT and $\mathbf{b}$ SGT 
swimming pools. The height of eight of the green roofs from the ground was more than $10 \mathrm{~m}$, with only ASH and MTK being less than $10 \mathrm{~m}$ height. The green roofs in this study could be divided into two groups based on their design. Seven green roofs (APR, ASH, MHT, MTK, NHP, PVE, and SGK) were of a garden bed design, while the other three (CPB, SXV, and SGT) were of a flowerpot design. Garden bed green roofs are constructed by directly planting vegetation in a continuous coverage substrate, whereas flowerpot green roofs use individual potted plants to create a rooftop garden. Figure 2 presents an example of a green roof appearance in this study.

The highest proportion of green roof and green area (66\%) was found on MHT. APR and ASH were the only green roofs with all four plant growth forms (trees, shrubs, herbs, and grass), and so, they provided the highest variety of vegetation growth forms. All green roofs contained trees and shrubs except for SGK, while herbs were not found on CPB, PVE, and SXV. Grasses were present on only APR, ASH, PVE, and SGK. In terms of plant abundance, MTK had the greatest number of shrubs and total plants, while ASH had the greatest number of trees as well as shrubs and all plant species. The APR rooftop had the greatest number of shrub species. Plants found on the study sites were commonly used species in landscape design for aesthetic and recreation. The exception was the plant species on SGK, which were mostly crops, such as Ocimum tenuiflorum and Ocimum basilicum.

\section{The RAC for assessment of GRES}

The developed RAC for assessment of GRES was composed of 46 proxy indicators (33 qualitative and 13 quantitative indicators). Some indicators could be used for the assessment of several services. Therefore, five regulating services (gas regulation, climate regulation, stormwater regulation, waste treatment, and pollination) were evaluated using 24 proxy indicators. To assess food provision (provisioning ecosystem service), 11 proxy indicators on the checklist were used. Three cultural services (aesthetic, recreation, and science and education) were estimated using 12 proxy indicators. Lastly, 12 proxy indicators of the RAC were collected in order to evaluate the habitat provision as part of the supporting service.

\section{Ecosystem service scores of selected green roofs in Bangkok}

The ecosystem service scores calculated from the RAC are presented in Table 4. All green roof study sites provided all of the four ecosystem service categories (regulating, provisioning, cultural, and supporting services), but to a varying extent. The ASH rooftop received the highest total ecosystem services score of 74 points, whereas SGT had the lowest total ecosystem service score of 48 , while the average total ecosystem service score of all ten rooftops was $61 \pm 7$. The average scores for the regulating and supporting services were the highest at $68 \pm 7$ and $67 \pm 6$, respectively. Lower scores were obtained for provisioning services $(53 \pm 11)$ and cultural service scores $(57 \pm 16)$. However, the scores for each of the ecosystem services were different among the green roofs included in this study.

For the regulating services, ASH had the highest score of 86 points while SGT had the lowest (59 points). SGK (rooftop farming) had the highest provisioning service score (82), while SXV had the lowest (36; poor). The cultural service score ranged from 79 points for ASH and PVE down to 27 points (poor) for SGT. Lastly, the supporting score ranged from 78 points $(\mathrm{ASH})$ down to 58 points (SGK).

Cluster analysis divided the ten green roofs into two distinct groups based on their relative ecosystem service scores (Additional file 2: Fig S1). The first group (APR, ASH, MHT, MTK, NHP, PVE, and SGK) were the green roofs that received a total ecosystem service score of more than 60 points, showing good and excellent performances in total ecosystem service provision. On the other hand, the second group (CPB, SGT, and SXV) showed a total ecosystem service score of less than 60 points (intermediate and poor performances in total ecosystem service provision). The green roofs in the first group clearly provided higher scores in the regulating and supporting services than the second group, which contributed to the higher overall total ecosystem service score (Fig. 3). No green roof was able to gain good or excellent scores in all four categories of ecosystem services (Fig. 3). Furthermore, a pair of ecosystem services showed significant positive correlations with good to strong relationships (Table 5), namely regulating and cultural services. On the other hand, regulating services

Table 4 Scores for the GRES evaluated by the RAC tool

\begin{tabular}{llllll}
\hline Study site & \multicolumn{5}{l}{ Ecosystem service scores (total of 100) } \\
\cline { 2 - 6 } & Regulating & Provisioning & Cultural & Supporting & Total \\
\hline APR & 74 & 45 & 59 & 70 & 62 \\
ASH & 86 & 55 & 79 & 78 & 74 \\
CPB & 62 & 55 & 33 & 75 & 56 \\
MHT & 70 & 55 & 62 & 75 & 65 \\
MTK & 68 & 45 & 60 & 69 & 61 \\
NHP & 68 & 55 & 56 & 68 & 61 \\
PVE & 71 & 55 & 79 & 62 & 66 \\
SGK & 62 & 82 & 65 & 64 & 68 \\
SGT & 59 & 45 & 27 & 59 & 48 \\
SXV & 63 & 36 & 49 & 58 & 52 \\
Average \pm SD & $68 \pm 7$ & $53 \pm 11$ & $57 \pm 16$ & $67 \pm 6$ & $61 \pm 7$ \\
\hline
\end{tabular}


(a)
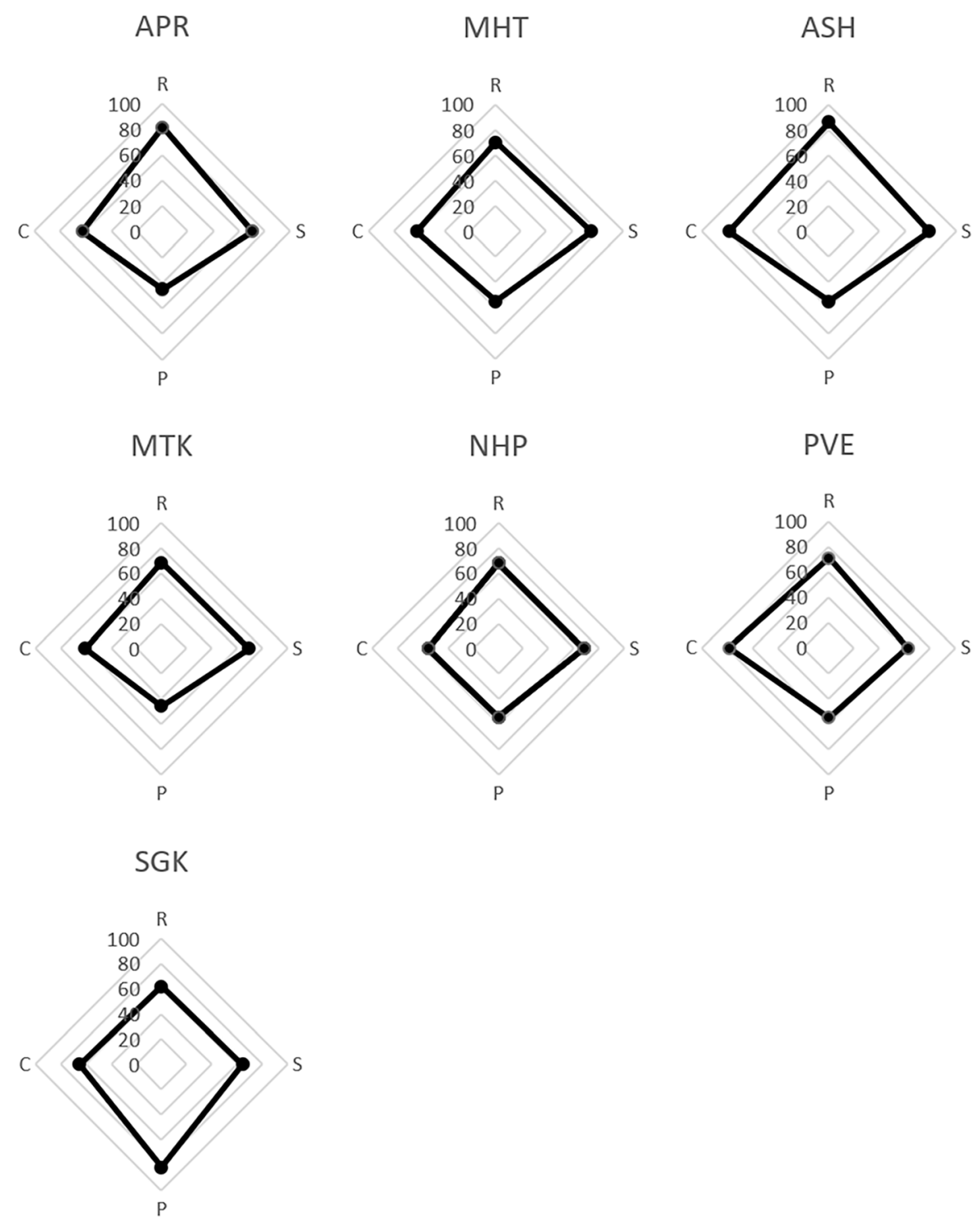

(b)

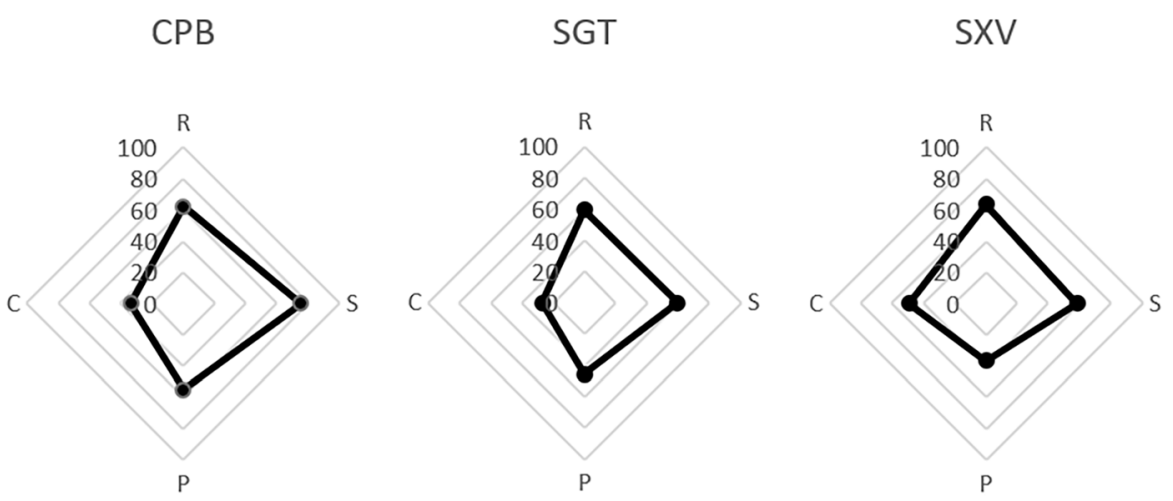

Fig. 3 (See legend on next page.) 
(See figure on previous page.)

Fig. 3 Radar chart of ecosystem service value on green roofs $(R=$ regulating services, $S=$ supporting services, $P=$ provisioning services, and $C=$ cultural services): a Green roofs with good and excellent performances in total ecosystem service provision and $\mathbf{b}$ green roofs with intermediate performances in total ecosystem service provision

correlated negatively with provisioning services, although the relationship was not statistically significant.

\section{Discussion}

\section{Efficiency of the RAC for estimation of GRES}

Currently, no existing tools have been used to simultaneously evaluate four aspects of ecosystem services (i.e., regulating, provisioning, cultural, and supporting services) on green roofs. Therefore, the current RAC tool was developed specifically and comprehensively for ecosystem service valuation at the local scale of green roofs, and so it should reflect the GRES values better than other general assessment tools.

Any assessment tool should have measurability, replicable results, credibility, flexibility, and affordability (Bagstad et al. 2013). This RAC was constructed using a composite indicator method (Alam et al. 2016), and normalized ecosystem service values were aggregated into total scores which are easily understandable even by non-specialists. The radar chart could present the relative ecosystem service values of the four main categories and could then be used as the baseline data for enhancing the quality of GRES.

In addition, the ecosystem service values were scored based on measurement and observation variables that were divided into different categories, where the resulting scores could be clearly considered. For example, in this study, the assessment of the green roof potential for carbon sequestration was scored using the green ratio and the two categories to be selected were "high" ( $\geq 75 \%, 1$ point) or "low" ( $<75 \%, 0.5$ point). Additionally, the ability of a green roof to provide habitats was evaluated using the occurrence of perching habitats on a green roof into the two categories of "high" (found, 1 point) or "low" (not found, 0 point). Assigning a score by category is a common method for a rapid assessment that potentially reduces the variability of scoring and so the error of measurement can be decreased (Fennessy et al. 2007). Therefore, this RAC tool could create replicable and robust ecosystem service values, although validation would still be required for more accurate outputs.

The accuracy of ecosystem service values depends on the quality of reference studies (Brenner et al. 2010). Accordingly, the proxy indicators in this RAC were carefully selected based on the suggestions or conclusions in previous research and recommendations in the expertbased guidelines. Therefore, this RAC could likely perform with sufficient accuracy and credibility. Although the GRES values were presented in proxy scores, which generally provide a lower accuracy than those obtained from direct measurements, the proxy scores allowed comparison among the different ecosystem services or different green roofs.

Any assessment tool should be applicable in various contexts. Even though generic indicators were used in this RAC, the indicators were able to estimate the preliminary ecosystem services of the selected green roofs. Moreover, because international standards have been used as the criteria for the indicators, this RAC tool is not limited for use only in Thailand, but could also be conducted in other countries. Using the RAC tool does not require specialized skills, and so it can be used by

Table 5 Correlation between the different GRES

\begin{tabular}{|c|c|c|c|c|c|}
\hline & & Regulating & Provisioning & Cultural & Supporting \\
\hline \multirow[t]{3}{*}{ Regulating } & Pearson correlation & 1 & -0.089 & $0.679^{*}$ & 0.602 \\
\hline & Sig. (two-tailed) & & 0.806 & 0.031 & 0.066 \\
\hline & $N$ & 10 & 10 & 10 & 10 \\
\hline \multirow[t]{3}{*}{ Provisioning } & Pearson correlation & -0.089 & 1 & 0.338 & 0.179 \\
\hline & Sig. (two-tailed) & 0.806 & & 0.340 & 0.622 \\
\hline & $N$ & 10 & 10 & 10 & 10 \\
\hline \multirow[t]{3}{*}{ Cultural } & Pearson correlation & $0.679^{*}$ & 0.338 & 1 & 0.282 \\
\hline & Sig. (two-tailed) & 0.031 & 0.340 & & 0.431 \\
\hline & $N$ & 10 & 10 & 10 & 10 \\
\hline \multirow[t]{3}{*}{ Supporting } & Pearson correlation & 0.602 & 0.179 & 0.282 & 1 \\
\hline & Sig. (two-tailed) & 0.066 & 0.622 & 0.431 & \\
\hline & $N$ & 10 & 10 & 10 & 10 \\
\hline
\end{tabular}

Correlation is significant at the ${ }^{*} 0.05$ or ${ }^{* *} 0.01$ level (two-tailed) 
both specialists and non-specialists. Specialists, who have technical knowledge that is relevant to GRES, can use the tool as preliminary indicators for the types and amounts of GRES. Non-specialists, such as building owners, officers, or gardeners, can also easily participate in the simple assessment process and understand the simple proxy scores of ecosystem services. However, the GRES in this study were evaluated by the researchers only because the usability by specialists was the main focus for this first version of the RAC tool. Therefore, in further studies, this RAC tool should be tested with non-specialists in parallel with specialists to confirm that it can be practically used by non-specialists.

This assessment was a preliminary estimation of GRES using a number of checklist items that were easy to evaluate and only required a small amount of time and effort to conduct. Fennessy et al. (2007) proposed the definition of rapid assessment as a process that is conducted by no more than two people and does not exceed a half-day total in the field and another half-day for preparation and analysis. Hence, this RAC tool achieved the definition of a rapid assessment because the users spent only a half-day for the checklist and less than a half-day for the analysis. Apart from that, this assessment also had the desirable attributes that were different from the conventional tools (Table 6), such as a low technical knowledge, manpower, and cost requirements, and so the participation of people in the evaluation process could be encouraged. Overall, the features and requirements of this RAC tool were similar to other rapid assessment tools, such as RAWES and TESSA.

This RAC tool could be applicable to the management and improvement of existing green roofs. The ability of a green roof as a provider for ecosystem services can be indicated by the GRES score obtained from the RAC. Therefore, each owner can realize what are the outstanding and the poor services of their green roof, and then can manage and maintain their green roofs appropriately in order to improve the poor services and sustain the good ones. Apart from that, the RAC tool can be also used for designing green roofs with a focus on ecosystem services. In the future, it can be applied as a collective learning game for the purpose of promoting green roofs and awareness of ecosystem services to the public. Although the accuracy and precision of results could be compromised by the use of proxy indicators, the efficacy of the checklist would be compensated for by the reduced time and effort required to conduct the assessment as well as the ease of use and understanding for the stakeholders involved. Therefore, to improve the accuracy of the ecosystem service estimation, more intensive and extensive methods would probably be required. Nevertheless, validation of the tool should be conducted in the future to increase its reliability and sensitivity for evaluating the GRES values.

\section{Adaptation of the RAC tool for more intensive outputs}

Public participation between users and landscape architects could facilitate the exchange of ideas and feedbacks and eventually make a holistic approach in urban green space design and construction process (Taib and Abdullah 2012). Thus, the involvement of the stakeholders, both specialists (e.g., architects, engineers, and ecologists) and non-specialists (e.g., building owners, officers, and gardeners), was considered during the construction of the checklist developed in this study. In particular, it was recognized that non-specialists might have limited technical knowledge on green roof ecosystems and little

Table 6 Comparison of key attributes of different ecosystem service assessment tools, derived from Peh et al. (2013) and Waage and Stewart (2008)

\begin{tabular}{|c|c|c|c|c|c|c|c|c|c|}
\hline $\begin{array}{l}\text { Assessment } \\
\text { tool }\end{array}$ & Description & Scope & $\begin{array}{l}\text { Intended } \\
\text { user(s) }\end{array}$ & $\begin{array}{l}\text { Data } \\
\text { requirement }\end{array}$ & $\begin{array}{l}\text { Academic } \\
\text { knowledge }\end{array}$ & Time & Manpower & Cost & Reference \\
\hline RAC-GRES & $\begin{array}{l}\text { Checklist tool for estimating } \\
\text { ecosystem services on green roofs }\end{array}$ & $\begin{array}{l}\text { Landscape- } \\
\text { local }\end{array}$ & $\begin{array}{l}\text { Specialists/ } \\
\text { non- } \\
\text { specialists }\end{array}$ & Low-high & Low & Low & Low & Low & This study \\
\hline $\begin{array}{l}\text { Corporate } \\
\text { ESR }\end{array}$ & $\begin{array}{l}\text { Qualitative tool for identifying, } \\
\text { prioritizing, and assessing impacts } \\
\text { of ecosystem services }\end{array}$ & $\begin{array}{l}\text { Landscape- } \\
\text { global }\end{array}$ & $\begin{array}{l}\text { Specialists/ } \\
\text { non- } \\
\text { specialists }\end{array}$ & Low & High & Low & Low & High & $\begin{array}{l}\text { Hanson } \\
\text { et al. } \\
(2012)\end{array}$ \\
\hline InVEST & $\begin{array}{l}\text { Computer-based tool for ecological } \\
\text { production and subsequent } \\
\text { economic valuation }\end{array}$ & $\begin{array}{l}\text { Landscape- } \\
\text { global }\end{array}$ & $\begin{array}{l}\text { Specialists/ } \\
\text { non- } \\
\text { specialists }\end{array}$ & Low-high & High & $\begin{array}{l}\text { Intermediate- } \\
\text { high }\end{array}$ & Low & High & $\begin{array}{l}\text { Sharp et al. } \\
(2016)\end{array}$ \\
\hline RAWES & $\begin{array}{l}\text { Checklist tool for assessing } 37 \\
\text { ecosystem services provided by a } \\
\text { wetland }\end{array}$ & Landscape & $\begin{array}{l}\text { Specialists/ } \\
\text { non- } \\
\text { specialists }\end{array}$ & Low-high & Low & Low & Low & Low & $\begin{array}{l}\text { Mclnnes } \\
\text { and } \\
\text { Everard } \\
(2017)\end{array}$ \\
\hline TESSA & $\begin{array}{l}\text { Suite of tools used for evaluating } \\
\text { and monitoring ecosystem services } \\
\text { at a site scale }\end{array}$ & Landscape & $\begin{array}{l}\text { Specialists/ } \\
\text { non- } \\
\text { specialists }\end{array}$ & Low-high & Low & Low & Low & Low & $\begin{array}{l}\text { Peh et al. } \\
(2013)\end{array}$ \\
\hline
\end{tabular}


time for conducting the assessment. Therefore, the RAC tool was created using proxy indicators and simple methods for data collection, such as general measurements and answering the multiple-choice and binary questions with a yes or no, in order to support their ability to perform the green roof assessment. However, this tool can be adapted to a more refined assessment if time and technical knowledge of the users are less limited and more accurate outputs are required. Then, proxy indicators whose values were acquired from more complicated methods can be included in the checklist. For example, the number of plants species that are present on the green roofs can be included in the assessment of supporting services (Baral et al. 2016), while the technical data of building temperature, solar radiation, relative humidity, and wind velocity can be collected to determine the regulating services of green roofs (microclimate control) (Lovell and Taylor 2013). The results of the modified assessment will then be presented in more refined numeric values. Although, in this RAC tool, some indicators could not be presented in scales, the outputs from the RAC tool could still demonstrate the potential of GRES that are informative for green roof management.

\section{Factors that influence GRES}

The overall scores from the assessment of GRES allowed the classification of the study sites into two groups: those with good (APR, ASH, MHT, MTK, NHP, PVE, and SGK) or intermediate (CPB, SGT, and SXV) ecosystem service performances. The results revealed that the design types likely influenced the clustering. Green roofs with a garden bed design were likely to provide a higher ecosystem service values than those with a flowerpot design.

Provisioning and cultural services were the limiting services in all rooftop gardens, and so the performance for providing total ecosystem services in this study could be indicated by the provisioning and cultural service values. Overall, the green roofs in this study provided higher levels of regulating and supporting services than provisioning and cultural services. This was probably because the regulating and supporting services are the benefits that are inherent to any ecosystem, including green roofs. Oberndorfer et al. (2007) reported that extensive green roofs were constructed for thermal insulation and stormwater management, while intensive green roof construction was for providing urban habitats. Therefore, although the intended function was for recreation in cultural services, such as at ASH, MHT, and MTK, the results indicated that the regulating and supporting services were still similar or higher than the cultural services. However, the cultural service values in this study were composed of aesthetic, recreation, and education values. When the value of each service was considered individually, such as only recreational or educational values, the service scores could reflect the intended function of the green roof, as proposed in Table 1. For example, ASH was constructed for a recreation purpose and obtained the highest recreational value score, while SGK had the highest educational value, which was consistent with its educational purpose. Nevertheless, in general, provisioning and cultural services values varied between the different green roofs depending on the characteristics of the green roofs, such as the use of edible plants, allowing the people to use a green roof, and conducting educational activities.

Based on the regulating scores that ranged from 59 to 86 , these ten green roofs could provide regulating services at intermediate, good, and excellent levels. The nine green roofs with trees (APR, ASH, CPB, MHT, MTK, NHP, PVE, SGK, and SXV) showed higher regulating service scores than SGT, which was of a flowerpot design with less than $50 \%$ tree cover. Trees are one of the important components that provide several ecosystem services. In terms of regulating services, the shade from trees can help to reduce the streets' surface and air temperatures (Richards and Edwards 2017). Moreover, trees are woody plants and so provide a higher potential for carbon storage than other non-woody vegetation forms (Fang et al. 2007). Trees can also help to remove pollutants from the atmosphere and show a better performance than shrubs or grass at removing air pollutants in urban cities (Jim and Chen 2008). Therefore, most of the green roofs with a tree cover of more than $50 \%$ in this study received regulating scores of more than 60 points.

The capability of those green roofs to provide regulating services was inferred from the scores as being good or excellent. Interestingly, SGK, the green roof with an absence of trees, provided a good level of regulating services, which was likely explained by the larger substrate coverage (green area). Substrates have important roles in several regulating services, such as water retention and runoff water purification (Lata et al. 2018). Green roofs that are composed of vegetation and substrate can help to increase the amount of permeable areas for runoff retention (Hjelm 2019). Hence, the potential in providing regulating services of green roofs should be greater when there is a larger substrate coverage area. Therefore, the potential for regulating services at SGT could be enhanced by planting more trees and installing more substrate coverage areas.

The green roofs in this study provided a wide and variable range of provisioning services. Although the scores were categorized into poor, intermediate, and excellent levels, and ranged from 36 to 82 , only the rooftop farming (SGK) showed a level above intermediate level (at excellent) for provisioning services. That SGK was rated 
excellent because it was constructed for a food production purpose, and so edible plants were carefully maintained by providing necessary facilities, such as a dripping irrigation system, for supporting food production. In contrast, APR, ASH, CPB, MHT, MTK, NHP, PVE, and SGT offered an intermediate level of provisioning services because these green roofs were not constructed for an agricultural purpose. Although some edible plants were found on APR, ASH, CPB, and SGT, there were only a few species and their products were not available or tested for marketable quality. Therefore, the plant products were not truly used or consumed, which resulted in a low provisioning service value. The MHT, MTK, NHP, and PVE rooftops lacked edible plants all together, but these green roofs could still provide some suitable conditions and facilities for supporting agriculture, such as substrate characters, sunlight hours, and water resources. Finally, SXV provided a poor provisioning service because the green roof lacked both edible plants and important requirements for rooftop agriculture. Hence, the provisioning service values identified the weakness and strengths of green roofs in a provisioning service aspect. However, depending on the initial objective and structural limitation of the green roof construction, food production may not be available on all green roofs.

The green roof study sites provided cultural services at poor, intermediate, and good levels, with scores ranging from 27 to 79. The cultural service scores of ASH, MHT, MTK, PVE, and SGK were classified as good, where ASH received the highest service score because it and SGK provided education activities. However, the total cultural service score of SGK was still lower than ASH due to its lack of recreation facilities. Although MHT, MTK, and PVE provided only aesthetic and recreation services, they were still evaluated with a good cultural service performance because there were higher numbers of green roof visitors compared to that for APR, NHP, and SXV, the green roofs with intermediate capability. Lastly, CPB and SGT provided a poor cultural service because access to this green roof was prohibited. No green roof provided cultural services at an excellent level due to the low level or lack of education services on these green roofs.

Supporting service scores ranged from 58 to 78 (intermediate to good level). The APR, ASH, CPB, MHT, MTK, NHP, PVE, and SGK rooftops provided a good performance in supporting services. Previous research suggested a positive correlation between the diversity of soil arthropods on green roofs and the vegetation cover (Schindler et al. 2011). Therefore, those green roofs composed of a high vegetation cover (more than 20\%) could serve a higher potential for habitat conservation. On the other hand, the supporting service scores were lower because of the occurrence of habitat fragmentation found in the flowerpot design of the SXV and SGT rooftops. According to Fahrig (2003), the patch size had an effect on biodiversity. Fewer species of fauna were found in smaller patches than larger patches. Therefore, using flowerpots could create smaller patches of habitat, and then the potential for habitat conservation would be limited and less than in a continuous substrate of garden bed green roofs.

\section{Tradeoffs and synergies in GRES}

The different ecosystem services provided by an ecosystem can influence each other (Turkelboom et al. 2015). Therefore, in addition to the factors mentioned above, the values of ecosystem services could also be affected by the relationships between services as shown by the correlations between the GRES proxy scores. Two types of relationship between ecosystem services found in this study were tradeoffs and synergies (Fig. 3). Tradeoffs can be observed when one ecosystem service is increased as a result of the decrease in another ecosystem service (Rodríguez et al. 2006). The negative relationship between the proxy scores of different ecosystem services could represent the tradeoffs among ecosystem services. A potential tradeoff between provisioning and regulating services was previously reported for green roofs. Harvesting for food production directly decreased the amount of carbon storage on the green roofs, while using fertilizer could enhance plant growth and food production, but could adversely influence the runoff quality of green roofs (Czemiel Berndtsson 2010).

However, the tradeoff between regulating and provisioning services in this study was defined as a good to strong relationship and was not significant. This could have resulted from the low number of study sites, and that only one green roof constructed purposely for provisioning services (food production) was evaluated. Nevertheless, the relationships between ecosystem services was previously investigated by Lee and Lautenbach (2016), who revealed that the tradeoff between regulating and provisioning services was predominant. Moreover, a negative correlation between soil fertility and forage availability was found in a temperate forest (Chillo et al. (2018). Therefore, the tradeoff(s) observed in this study were consistent with those previous studies in other natural ecosystems. However, more study sites would be required to understand ecosystem tradeoffs and relevant mechanisms.

Positive relationships could represent synergies among ecosystem services, the opposite of tradeoffs (Howe et al. 2014). Potential synergy between regulating and cultural services was found on the green roofs in this study. A combination of vegetation species on green roofs can 
help to increase their survivability (Nagase and Dunnett 2010 ), and so green roofs with a diverse vegetation mix would presumably perform their regulating services better than those with monoculture vegetation. Similarly, a greater vegetation diversity on green roofs in Spain was preferred by people (Fernandez-Cañero et al. 2013), showing the synergy and inferring that the aesthetic value in cultural services could be enhanced by adding plant species to green roofs.

The quality of urban life can be influenced by urban ecosystem services and then enhanced by locally generated ecosystem services (Bolund and Hunhammar 1999). The more ecosystem services that are provided, the better human life is. Then, the possibility of green roofs for substantially serving the four main categories of ecosystem services should be considered in urban landscape design and management. Due to the tradeoffs between ecosystem services on green roofs, the ecosystem services could be limited in both the potential and number of service types. Nevertheless, tradeoffs and synergies among ecosystem services are not fixed, and the relationships can change in space and time because of ecological processes and policies (Bennett et al. 2009). Therefore, management of green roofs should be considered wisely in order to mitigate tradeoffs or to enhance synergies. For instance, using biological fertilizers instead of chemical fertilizers or pesticides on green roofs can help to reduce the tradeoff between regulating and provisioning services by improving the storm water runoff quality without affecting the production yield. However, in practice, the management for improving the ecosystem service will depend on the perspective of the green roof's owner. This is because of some limitations, such as limited resources, green roof structure, or the intended functions, will limit multiple ecosystem services as some services are probably not suitable or necessary from the owner's perspective. However, in terms of ecosystems, green roofs that provide a good performance in all of four ecosystem service types are recommended, then the ways to satisfy both sides, usability and ecosystem aspects of green roofs, should be investigated in the future.

\section{Conclusions}

The recognition of GRES helps people to have a greater consideration for the management of green roofs as well as urban ecosystems. For this, a quantification tool for assessment of ecosystem services is needed in order to obtain the ecosystem service values. The RAC tool developed in this study was the first attempt to estimate all GRES. The checklist of proxy indicators can be used as rapid assessment tool and provide reliable assessment results of four main ecosystem services. We concluded that green roofs provided different ecosystem services at different levels because of the influences of characteristics of green roofs, vegetation, and management. The evaluation of GRES using the RAC tool could be used by owners to improve the quality of the GRES. In addition, this RAC tool also has important attributes, including measurability, flexibility, and affordability, which would allow both specialist and non-specialist users to adopt it. However, validation of the RAC tool should be performed in further studies. Moreover, the participation of non-specialists, such as building owners, officers, or gardeners, in the assessment process should be also investigated to ensure that they can easily understand and use the tool. The participation of stakeholders involved in the assessment process may increase the recognition of the capability of GRES provision. This may eventually lead to the installation of more green roofs and a better awareness of environmental conservation. Therefore, this RAC tool can be the first step in the estimation of whole GRES and indicate the strengths and limitations of green roofs in terms of provision of the different ecosystem services. Furthermore, in addition to the architectural and engineering expertise, this checklist could possibly be used for designing ecosystem service-based green roofs.

\section{Supplementary information}

Supplementary information accompanies this paper at https://doi.org/10. 1186/s13717-020-00222-z.

Additional file 1: Table S1. Indicators used in the rapid assessment checklist for the assessment of green roof ecosystem services.

Additional file 2: Fig S1. Classification of green roofs based on total ecosystem service values.

\section{Abbreviations}

APR: Aor Por Ror BuildingASHAnantara Siam Bangkok HotelCPBCrowne Plaza Bangkok Lumpini Park HotelESCEcosystem Services CompositeESREcosystem Services ReviewGREsGreen Roof EcosystemsGRESGreen roofs Ecosystem ServicesInVESTIntegrated Valuation of Ecosystem Services and

TradeoffsMHTMahitaladhibesra BuildingMTKMitkorn MansionNHPNoble House PhayathaiPVEPark Venture EcoplexRACRapid Assessment ChecklistSGKSiam Green SkySGTSG Tower BuildingSXV60th Anniversary BuildingTESSAToolkit for Ecosystem Service Site-based Assessment

\section{Acknowledgments}

We thank the building owners for permission to use their green roofs as the study sites. We thank the Development and Promotion of Science and Technology Talents Project for the scholarship, and Graduate School of Education, Yonsei University, College of Agriculture and Life Science, Seoul National University, and the Department of Biology, Faculty of Science, Chulalongkorn University for facility supports.

\section{Authors' contributions}

RP designed research methods, conducted the field work, analyzed and cured the data, and wrote the original manuscript. TYP and DKL provided scientific advices for editing the manuscript. NPD and PD designed research methods, co-analyzed the data, improved the original manuscript, substantively revised the manuscript, and acquired funding. All authors read and approved the final manuscript. 


\section{Funding}

This research was supported by the 90th Anniversary of Chulalongkorn University, Rachadapisek Sompote Fund (GCUGR1125603028D No.25). RP was financially supported by the Development and Promotion of Science and Technology Talents Scholarship.

\section{Availability of data and materials}

The datasets used and/or analyzed during the current study are available from the corresponding author on reasonable request.

\section{Ethics approval and consent to participate}

Not applicable

\section{Consent for publication}

Not applicable

\section{Competing interests}

The authors declare that they have no competing interests.

\section{Author details}

${ }^{1}$ Biological Sciences Program, Faculty of Science, Chulalongkorn University, Bangkok 10330, Thailand. 'Department of Biology, Faculty of Science, Chulalongkorn University, Bangkok 10330, Thailand. ${ }^{3}$ Graduate School of Education, Yonsei University, Seoul 03722, Republic of Korea. ${ }^{4}$ Department of Landscape Architecture and Rural System Engineering, Seoul National University, Seoul 08826, Republic of Korea.

\section{Received: 29 October 2019 Accepted: 20 February 2020}

\section{Published online: 08 April 2020}

\section{References}

Alam M, Dupras J, Messier C (2016) A framework towards a composite indicator for urban ecosystem services. Ecological Indicators 60:38-44. https://doi.org/ 10.1016/j.ecolind.2015.05.035

Bagstad KJ, Semmens DJ, Waage S, Winthrop R (2013) A comparative assessment of decision-support tools for ecosystem services quantification and valuation. Ecosystem Services 5:27-39. https://doi.org/10.1016/j.ecoser.2013.07.004

Banting D, Doshi H, Li J, Missios P (2005) Report on the environmental benefits and costs of green roof technology for the city of Toronto. City of Toronto and Ontario Centres for Excellence-Earth and Environmental Technologies, Toronto

Baral H, Guariguata MR, Keenan RJ (2016) A proposed framework for assessing ecosystem goods and services from planted forests. Ecosystem Services 22: 260-268. https://doi.org/10.1016/j.ecoser.2016.10.002

Bennett EM, Peterson GD, Gordon LJ (2009) Understanding relationships among multiple ecosystem services. Ecology Letters 12:1394-1404

Berardi U, GhaffarianHoseini A, GhaffarianHoseini A (2014) State-of-the-art analysis of the environmental benefits of green roofs. Applied Energy 115:411-428. https://doi.org/10.1016/j.apenergy.2013.10.047

Bieling C, Plieninger T (2013) Recording manifestations of cultural ecosystem services in the landscape. Landscape Research 38:649-667

Bolund P, Hunhammar S (1999) Ecosystem services in urban areas. Ecological Economics 29:293-301. https://doi.org/10.1016/S0921-8009(99)00013-0.

Brenner J, Jiménez JA, Sardá R, Garola A (2010) An assessment of the non-market value of the ecosystem services provided by the Catalan coastal zone, Spain. Ocean \& Coastal Management 53:27-38. https://doi.org/10.1016/j. ocecoaman.2009.10.008

Brown S (2010) Likert scale examples for surveys. lowa State University. https:// www.extension.iastate.edu/Documents/ANR/LikertScaleExamplesforSurveys. pdf Accessed 21 January 2018

Carter T, Fowler L (2008) Establishing green roof infrastructure through environmental policy instruments. Environmental Management 42:151-164

Chillo V, Vázquez DP, Amoroso MM, Bennett EM (2018) Land-use intensity indirectly affects ecosystem services mainly through plant functional identity in a temperate forest. Functional Ecology 32:1390-1399

Cook-Patton SC, Bauerle TL (2012) Potential benefits of plant diversity on vegetated roofs: a literature review. Journal of Environmental Management 106:85-92. https://doi.org/10.1016/j.jenvman.2012.04.003

Currie BA, Bass B (2008) Estimates of air pollution mitigation with green plants and green roofs using the UFORE model. Urban Ecosystems 11:409-422
Czemiel Berndtsson J (2010) Green roof performance towards management of runoff water quantity and quality: a review. Ecological Engineering 36:351360. https://doi.org/10.1016/j.ecoleng.2009.12.014

Daniel TC, Muhar A, Arnberger A, et al. (2012) Contributions of cultural services to the ecosystem services agenda. Proceedings of the National Academy of Sciences of the United States of America 109:8812-8819

Egoh B, Drakou EG, Dunbar MB, Maes J, Willemen L (2012) Indicators for mapping ecosystem services: a review. Publications Office of the European Union, Luxembourg

Fahrig L (2003) Effects of habitat fragmentation on biodiversity. Annual Review of Ecology, Evolution and Systematics 34:487-515

Fang S, Xue J, Tang L (2007) Biomass production and carbon sequestration potential in poplar plantations with different management patterns. Journal of Environmental Management 85:672-679. https://doi.org/10.1016/j. jenvman.2006.09.014

Fennessy MS, Jacobs AD, Kentula ME (2007) An evaluation of rapid methods for assessing the ecological condition of wetlands. Wetlands 27:543-560

Fernandez R, Gonzalez-Redondo P (2010) Green roofs as a habitat for birds: a review. Journal of Animal and Veterinary Advances 9:2041-2052

Fernandez-Cañero R, Emilsson T, Fernandez-Barba C, Herrera Machuca MÁ (2013) Green roof systems: a study of public attitudes and preferences in southern Spain. Journal of Environmental Management 128:106-115. https://doi.org/ 10.1016/j.jenvman.2013.04.052

FLL (2008) Guidelines for the planning, construction and maintenance of green roofing - green roofing guideline. Forschungsgesellschaft Landschaftsentwicklung Landschaftsbau (FLL), Bonn

FoodShare (2015) Community Gardens - Rooftop Gardening. https://foodshare. net/custom/uploads/2015/11/Rooftop_Gardening.pdf.

Francis LFM, Jensen MB (2017) Benefits of green roofs:a systematic review of the evidence for three ecosystem services. Urban Forestry \& Urban Greening 28: 167-176. https://doi.org/10.1016/j.ufug.2017.10.015

Germain A, Grégoire B, Hautecoeur I, Ayalon R, Bergeron A (2008) Guide to setting up your own edible rooftop garden. http://archives2019. rooftopgardens.alternatives.ca//sites/rooftopgardens.alternatives.ca/files/ ready_to_grow.pdf.pdf.

Getter KL, Rowe DB (2006) The role of extensive green roofs in sustainable development. HortScience 41:1276-1285

Getter KL, Rowe DB, Robertson GP, Cregg BM, Andresen JA (2009) Carbon sequestration potential of extensive green roofs. Environmental Science \& Technology 43:7564-7570

Ghermandi A, Fichtman E (2015) Cultural ecosystem services of multifunctional constructed treatment wetlands and waste stabilization ponds: time to enter the mainstream? Ecological Engineering 84:615-623. https://doi.org/10.1016/ j.ecoleng.2015.09.067

Grunewald K, Bastian O (2017) Special Issue: "Maintaining Ecosystem Services to Support Urban Needs". Sustainability 9:1647

Haase D, Larondelle N, Andersson E, Artmann M, Borgström S, Breuste J, Elmqvist TJA (2014) A quantitative review of urban ecosystem service assessments: concepts, models, and implementation. Ambio 43:413-433. https://doi.org/ 10.1007/s13280-014-0504-0

Hanson C, Ranganathan J, Iceland C, Finisdore J (2012) The corporate ecosystem services review: guidelines for identifying business risks and opportunities arising from ecosystem change. World Resources Institute, Washington, DC

Hjelm J (2019) Green roof performance in cold climates : a study on how different plants suited for the subarctic climate in northern Sweden affects the performances of green roofs. Luleå University of Technology, Thesis

Home Garden Seed Association (HGSA) (2015) Pollinators in the city. https:// www.homegardenseedassociation.com/s/2015-spring-press-release.pdf.

Howe C, Suich H, Vira B, Mace GM (2014) Creating win-wins from trade-offs? Ecosystem services for human well-being: a meta-analysis of ecosystem service trade-offs and synergies in the real world. Global Environmental Change 28:263-275. https://doi.org/10.1016/j.gloenvcha.2014.07.005

Hsu A, Zomer A (2014) Environmental performance index. Wiley StatsRef, Statistics Reference Online, pp 1-5. https://doi.org/10.1002/9781118445112.stat03789.pub2

Hui S, Chan KL (2011) Biodiversity assessment of green roofs for green building design. Proceedings of Joint Symposium 1-11

Huppes G, van Oers L (2011) Evaluation of weighting methods for measuring the EU-27 overall environmental impact. Publications Office of the European Union, Luxembourg 
Hurley PT, Emery MR (2018) Locating provisioning ecosystem services in urban forests: forageable woody species in New York City, USA. Landscape and Urban Planning 170:266-275. https://doi.org/10.1016/j.landurbplan.2017.09.025

Jim CY, Chen WY (2008) Assessing the ecosystem service of air pollutant removal by urban trees in Guangzhou (China). Journal of Environmental Management 88:665-676. https://doi.org/10.1016/j.jenvman.2007.03.035

Jungels J, Rakow DA, Allred SB, Skelly SM (2013) Attitudes and aesthetic reactions toward green roofs in the Northeastern United States. Landscape and Urban Planning 117:13-21. https://doi.org/10.1016/j.landurbplan.2013.04.013

Kim E, Jung J, Hapsari G, Kang S, Kim K, Yoon S, et al. (2018) Economic and environmental sustainability and public perceptions of rooftop farm versus extensive garden. Building and Environment 146:206-215. https://doi.org/10. 1016/j.buildenv.2018.09.046

Lata JC, Dusza Y, Abbadie L, et al. (2018) Role of substrate properties in the provision of multifunctional green roof ecosystem services. Applied Soi Ecology 123:464-468. https://doi.org/10.1016/j.apsoil.2017.09.012

Lee $\mathrm{H}$, Lautenbach S (2016) A quantitative review of relationships between ecosystem services. Ecological Indicators 66:340-351. https://doi.org/10.1016/ j.ecolind.2016.02.004

Lovell ST, Taylor JR (2013) Supplying urban ecosystem services through multifunctional green infrastructure in the United States. Landscape Ecology 28:1447-1463

Maclvor JS (2016) Building height matters: nesting activity of bees and wasps on vegetated roofs. Israel Journal of Ecology \& Evolution 62:88-96

McInnes RJ, Everard M (2017) Rapid Assessment of Wetland Ecosystem Services (RAWES): an example from Colombo, Sri Lanka. Ecosystem Services 25:89105. https://doi.org/10.1016/j.ecoser.2017.03.024

Mentens J, Raes D, Hermy M (2006) Green roofs as a tool for solving the rainwater runoff problem in the urbanized 21 st century? Landscape and Urban Planning 77:217-226. https://doi.org/10.1016/j.landurbplan.2005.02.010

Millennium Ecosystem Assessment (2005) Ecosystems and human well-being: synthesis. Island Press, Washington, DC

Mocior E, Kruse M (2016) Educational values and services of ecosystems and landscapes - an overview. Ecological Indicators 60:137-151. https://doi.org/ 10.1016/j.ecolind.2015.06.031

Nagase A, Dunnett N (2010) Drought tolerance in different vegetation types for extensive green roofs: effects of watering and diversity. Landscape and Urban Planning 97:318-327. https://doi.org/10.1016/j.landurbplan.2010.07.005

Nardo M, Saisana M, Saltelli A, Tarantola SJEC (2005) Tools for composite indicators building. European Commission, Ispra

Oberndorfer E, Lundholm J, Bass B, et al. (2007) Green roofs as urban ecosystems: ecological structures, functions, and services. BioScience 57:823-833

Office of Natural Resources and Environmental Policy and Planning (2014) Standard for city green space and suitable plants for green space. Ministry of Natural Resources and Environment, Bangkok

Peh KSH, Balmford A, Bradbury RB, et al. (2013) TESSA: A toolkit for rapid assessment of ecosystem services at sites of biodiversity conservation importance. Ecosystem Services 5:51-57. https://doi.org/10.1016/j.ecoser. 2013.06.003

Permpituck S, Namprakai P (2012) The energy consumption performance of roof lawn gardens in Thailand. Renewable Energy 40:98-103. https://doi.org/10. 1016/j.renene.2011.09.023

Pianella A, Aye L, Chen Z, Williams N (2017) Substrate depth, vegetation and irrigation affect green roof thermal performance in a Mediterranean type climate. Sustainability 9:1451

Pollution Control Department (2013) Guideline for green building assessment. Ministry of Natural Resources and Environment, Bangkok

Richards DR, Edwards PJ (2017) Quantifying street tree regulating ecosystem services using Google Street View. Ecological Indicators 77:31-40. https://doi. org/10.1016/j.ecolind.2017.01.028

Rodríguez JP, Beard TD, Bennett EM, et al. (2006) Trade-offs across space, time, and ecosystem services. Ecology and Society 11:28

Rowe DB (2011) Green roofs as a means of pollution abatement. Environmental Pollution 159:2100-2110. https://doi.org/10.1016/j.envpol.2010.10.029

Rowe DB, Monterusso MA, Rugh CL (2006) Assessment of heat-expanded slate and fertility requirements in green roof substrates. HortTechnology 16:471477

Sala S, Cerutti AK, Pant R (2018) Development of a weighting approach for the environmental footprint. Publications Office of the European Union, Luxembourg
Schindler BY, Griffith AB, Jones KN (2011) Factors influencing arthropod diversity on green roofs. Cities and the Environment (CATE) 4:5

Sfakianaki A, Pagalou E, Pavlou K, Santamouris M, Assimakopoulos MN (2009) Theoretical and experimental analysis of the thermal behaviour of a green roof system installed in two residential buildings in Athens, Greece. International Journal of Energy Research 33:1059-1069

Sharp R, Tallis HT, Ricketts T, et al. (2016) InVEST+ VERSION+ User's Guide. The Natural Capital Project, Stanford

Sharpe A, Andrews B (2012) An assessment of weighting methodologies for composite indicators: the case of the index of economic well-being. Centre for the Study of Living Standards, Ontario

Sieber J, Fremgen L, Pons M (2015) Assessment of ecosystem services for urban resilience - case study in Singapore. Planet@Risk 3:77-86

Stone B, Vargo J, Habeeb D (2012) Managing climate change in cities: will climate action plans work? Landscape and Urban Planning 107:263-271. https://doi.org/10.1016/j.landurbplan.2012.05.014

Taib N, Abdullah A (2012) Study of landscape gardens: expectations and users' perceptions of a high-rise office building. Procedia - Social and Behavioral Sciences 50:633-642. https://doi.org/10.1016/j.sbspro.2012.08.066

Talukder B, Hipel KW, vanLoon GW (2017) Developing composite indicators for agricultural sustainability assessment: effect of normalization and aggregation techniques. Resources 6:66

Torrance S, Bass B, Maclvor JS, McGlade T (2013) City of Toronto guidelines for biodiverse green roofs. Toronto City Planning, Toronto

Turkelboom F, Thoonen M, Jacobs S, Berry P (2015) Ecosystem service trade-offs and synergies. Ecology and Society 21:43

U.S. Fish and Wildlife (2014) Supporting the health of honey bees and other pollinators. https://www.fws.gov/southwest/es/Documents/R2ES/ Pollinators/6-Supporting_the_Health_of_Honey_Bees_and_Other_ Pollinators_Oct2014.pdf.

Vijayaraghavan K, Joshi UM (2014) Can green roof act as a sink for contaminants? A methodological study to evaluate runoff quality from green roofs. Environmental Pollution 194:121-129. https://doi.org/10.1016/j.envpol.2014. 07.021

Waage S, Stewart E (2008) Ecosystem services management: a briefing on relevant public policy developments and emerging tools. Flora \& Fauna International.

Wang JW, Poh CH, Tan CYT, Lee VN, Jain A, Webb EL (2017) Building biodiversity: drivers of bird and butterfly diversity on tropical urban roof gardens. Ecosphere 8(9):e01905

Whittinghill $\sqcup$, Rowe DB, Cregg BM (2013) Evaluation of vegetable production on extensive green roofs. Agroecology and Sustainable Food Systems 37: 465-484

Whittinghill L, Rowe DB, Schutzki R, Cregg BM (2014) Quantifying carbon sequestration of various green roof and ornamental landscape systems. Landscape and Urban Planning 123:41-48. https://doi.org/10.1016/j. landurbplan.2013.11.015

Williams NSG, Lundholm J, Scott Maclvor J (2014) Do green roofs help urban biodiversity conservation? Journal of Applied Ecology 51:1643-1649

Yang J, Yu Q, Gong P (2008) Quantifying air pollution removal by green roofs in Chicago. Atmospheric Environment 42:7266-7273. https://doi.org/10.1016/j. atmosenv.2008.07.003

\section{Publisher's Note}

Springer Nature remains neutral with regard to jurisdictional claims in published maps and institutional affiliations. 